\title{
Characteristic of oral biofilm infectious diseases
}

Katsuji Okuda

The review article shows the characteristic of oral biofilm infectious diseases. Oral bacterial species possess biofilm-forming activity on the surface of tooth, periodontal region, dorsum of tongue, buccal epithelium, dental implant, and denture as a unique ecosystem. Dental plaque is known as the typical biofilm consisting the community with various kinds of bacteria. Our studies have suggested that oral biofilm organisms may play a role in the etiology of various kinds of systemic diseases. We examined oral bacteria in samples from atherosclerotic lesions including cardiovascular disease. Treponema denticola 16S rRNA and the antigen were found in 6 out of 26 DNA samples from the formalin-fixed, paraffin-embeded atherosclerotic lesions obtained during surgery, but not in any of the 14 non-diseased aorta samples. We also detected periodontal disease-associated bacteria in samples of cardiovascular diseases. We found that oral bacteria are able to trap Helicobacter pylori that is known to cause gastritis and peptic ulcer disease, but inhibited H. pylori growth. Periodontopathic Campylobacter rectus strains possess crossreactive antigens including heat shock proteins with $H$. pylori strains suggesting that antigens of $C$. rectus may be related to the induction of immunopathological responses. We also found the relationship between paeriodontal disease-associated bacterial heat shock proteins and pustulosis palmaris et plantaris. The significance of oral care for elderly requiring nursing care was demonstrateel. We also discussed the denture and implant biofilms in the review.

口腔バイオフィルム感染症の特徴について解説した，口腔細菌は歯面，歯周組織，舌背，頬粘膜，義歯やインプ ラントなどに定着して, バイオフィルムとなって持続感染している。デンタルプラークは, 複数の細菌がコミュニ イティーをつくる特徴のあるバイオフィルムとなる，口腔内バイオフィルムからとびだす細菌は，全身性の疾患に 密接にかかわっているという多くの証明がなされてきた。私たちは, 動脈疾患部位に歯周病原菌が検出されるかを 調べ，26人の動脈疾患部の6部位にTreponema denticolaのDNAならびに抗原を見つけた。しかし，健康な動脈には 歯周病原菌は検出されなかった。また, 心臓冠状動脈疾患部位の材料中にも, 㐘周病原菌のDNAを検出した. 胃潰 瘍などのリスク因子であるHelicobacter pylori と歯周病原菌との関係についても明らかにした。歯周病原性Campylobacter rectusは，H. pylori と共通する抗原を有することによって H. pylori感染胃疾患と関倸することを指摘した． さらに, 歯周病原菌の熱ショック蛋白質が掌蹠膿疮症に関与していることも示した。本解説では, 要介護高齢者に 対する口腔ケアの意義についても記載した。

Key words : バイオフィルム biofilm, 感染症 infectious diseases, デンタルプラーク dental plaque, 歯科臨床 dental clinic, 口腔ケア oral care, メカニカル清掃 mechanical cleansing 


\section{はじめに}

多くの細菌学者は，パスッール以来，ある意味にお いて間違った研究を積み重称てきた。自然界に存在す る細菌は，浮遊した planktonic cells として存在するの ではなく, 集団となって何かに付着して層状になった バイオフィルム (biofilm) として生存している. 細菌 学者は, 試験管やフラスコで培養して浮遊した細菌を 集めていろいろ検討していたが, 実際には多くの細菌 はバイオフィルムとなっていることを念頭に入れてこ なかった ${ }^{1.2}$.

細菌は, 自分たちが棲み着いて増殖できる環境では, シグナルを出して一定の数に達する。そして, 自分た ちの棲む環境が悪くなると, シグナルを出して増殖を ストップさせている。細菌同士がそのような情報伝達 に使うシグナルは, 細菌性フェロモンあるいはホルモ ンともいえる。また，自分自身の形質を誘導すること から自己誘導体 (autoinducer；AI）といわれる ${ }^{3-6}$. 遺伝子の受け渡し, 菌が栄養源を求めて運動する走化 性, 菌の増殖の停止, 菌の生き残り, 毒素産生性, 白 血球の食菌や殺菌から逃れるための萊膜形成, 蛋白質 の分泌，抗菌剂に対する抵抗性など多くの因子が自己 誘導される。

自己誘導で, 最も早くから解明されてきたものが, 菌の密度を調節するQS システム (quorum sensing system）といわれるものである. Quorumとは, 会議に参 加する定数のことで, sensingは, 感知するということ

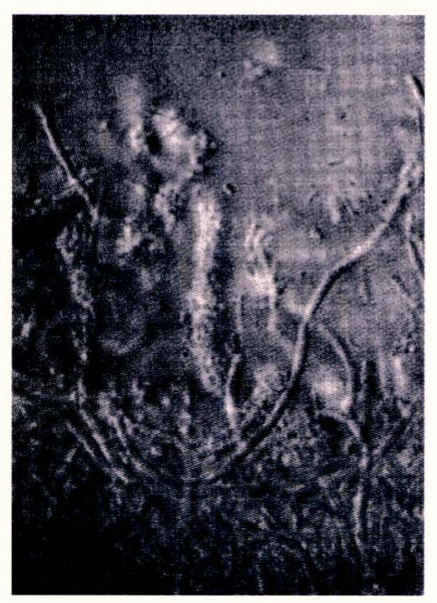

図 1 デンタルプラークという バイオフィルムは, 複数 の細菌種によって構成さ れる. 球菌が多く観察さ れるが，芯になる大型の 長い細菌種もみられる. シグナルを出してコミュ ニティーをつくっている
である。多くの細菌は、このQS シグナルを産生して それぞれの増殖する場所で自分たちの密度を調節し， 病原性にかかわる様々な因子の産生を調節している。

デンタルプラークは，複数の細菌が形成するバイオ フィルムの典型的なものである（図１）。デンタルプ ラークの多くの細菌は, 細胞間情報伝達物質である QS シグナルをもっていることによって，それぞれの 部位で縄張りを築き，バイオフィルムである生態系 (ecosystem) を築いている.

\section{バイオフィルム形成細菌のシグナル}

細菌が産生する QS シグナル分子は, 細菌の細胞質膜 などを自由に通過するため周囲の細菌に伝達される。 QS シグナルを出すものは, 緑膿菌, セラチア菌, 大腸 菌, エルシニア菌, そして歯周病原性グラム陰性菌群 などである。一方，黄色ブドウ球菌，肺炎球菌などの グラム陽性菌群が産生する QS シグナルは,ペプチド 。 フェロモン (peptide pheromone) で, 菌の密度に同調し て産生される ${ }^{4}$ 。したがって，これらのQSシグナルを 産生する菌群は，菌の密度をあげてバイオフィルムを 形成する。そして，バイオフィルムは菌の集団である ため持続感染となってしまう4.5)。また，ICUなどでは 命のパイプとなるカテーテルなどにバイオフィルムを 形成し，院内感染を引き起こしてしまうこともある1”. 義歯に付着するバイオフィルムは, 主としてCandida albicansなどであり，いわゆるデンチャープラークを 形成している。したがって，清掃のよくないレジン面 では，C. albicansなどがバイオフィルムを形成するた めヌルヌルしてしまう。

\section{バイオフィルム形成プロセス}

QS シグナルを産生する細菌は，それぞれの環境で 自分たちが棲み着きやすくするためにバイオフィルム を形成する。感染した部位で集団となり, 宿主防御入 カニズムや抗菌剂に抵抗して持続感染できる環境を築 きあげる。

バイオフィルム形成の最初の段階は, 浮遊菌が表面 へ付着することである。次の段階は，小さな集落を形 


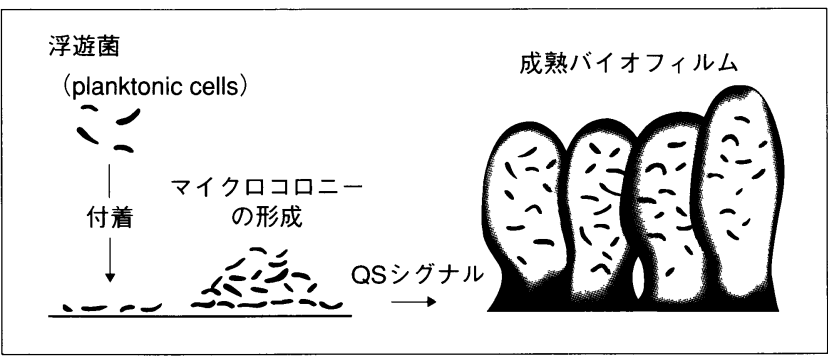

図2 バイオフィルム形成プロセス。 浮遊した細菌が付着して マイクロコロニーを形成後，きのこ状に細菌の集団となり， ヌルヌルしたバイオフィルムになる. 歯肉緑上デンタルプラ 一クだけでなく，歯周ポケット内細菌もシグナルを出して菌 塊となって持続感染する. 歯周ポケット内のバイオフィルム から流出した浮遊菌は，歯肉内緑上皮を貫通する．また，産 生された内毒素（エンドトキシン）は，歯内内緑上皮や滲出 した細胞のレセプターに結びつき，血流に入り込む．抗菌剤 はバイオフィルムに滲透できない，そのため，ブラシや超音 波処理などのメカニカルな除去が不可欠といえる

成することである，小さな集団となる際，集団の菌は 運動を停止している，大きな集団となる場合には，細 菌どうしが情報をやり取りするためにQS シグナルを 産生する，バイオフィルムは，図2に示したように， 成熟すると，きのこ状になる，成熟したバイオフィル ムは均一ではなく, 水を通すチャネルがつくられる4,5). チャネルを介して栄養源を取り入れたり，自分たちの 環境を破壊するような老廃物を排出する。

バイオフィルムは，産生するヌルヌルの本態は，菌 体外に合成する多糖体で, glycocalyx（糖衣）と呼ばれ る。緑膿菌がつくる多糖体はアルギネート（alginate） である. Glycocalyxは，ムコイド (mucoid) や菌体外 多糖物質（extracellular polymeric substance；EPS）など とも呼ばれる゙。.

\section{バイオフィルムは生涯へばりつく}

私たちの体には，生まれつきにもっている非特異的 な，いわゆる自然免疫と生後成立する特異的な獲得免 疫が働いており，外部から侵入する非自己を排除する 防御機能が備わっている". 蛋白質抗原に対しては, 速やかに $\mathrm{T}$ 細胞や $\mathrm{B}$ 細胞が反応する。ところが，バイ オフィルム形成物質といえる多糖体抗原である glycocalyxに対しては, T細胞が関与しないため免疫学的応 答が容易に起きてこない。そのため, glycocalyx を破
壊するような免疫応答はほとんど起こらない22.

また，バイオフィルム排除に作用するような特異性 のある抗体が産生されたとしても，バイオフィルムの 表面の細菌にしか作用しない.さらに, 食細胞が関連 する免疫学的応答は, バイオフィルムの表面の菌体を 駆逐することができても，集団となっているバイオフ イルム菌体を食菌して殺菌することはできない.

口腔内では, 唾液中の分泌型 $\operatorname{IgA}$ が細菌の付着を阻 止しょうと作用している。唾液中に多い分泌型IgAは， 蛋白質抗原に作用する $\operatorname{IgA} 1$ サブクラスである。バイ オフィルムのマトリックスなどの多糖体抗原に作用す るIgA 2サブクラスは唾液中に少ないため, 形成され たバイオフィルムの破壞に作用する働きは弱い1．し たがって，唾液の分泌型 $\operatorname{IgA}$ の中心的役割は，バイオ フィルム形成の初期段階である付着阻止である.

\section{歯周病原性細菌がつくるバイオフィルムの病原性}

歯周病原性Fusobacterium nucleatum, Porphyromonas gingivalis, Prevotella intermediaが，バイオフィルム形 成に関連するシグナル分子を産生することが明らかに された ${ }^{2}$.また, P. gingivalisがバイオフィルム形成に かかわる遺伝子は，様々な病原性因子の発現を規制し ていることが解明された ${ }^{2)}$. さらに, 歯周病原性Actinobacillus actinomycetemcomitans は，自己誘導物質を産 生して外毒素である白血球毒素（leukotoxin）の産生 を調節し，P. gingivalisのバイオフィルム形成遺伝子に 作用する ${ }^{2)}$. すなわち, A. actinomycetemcomitans は, 会話することによって産生する白血球毒素量を調整 し，他菌種であるP. gingivalisにも会話して影響を与 えることが明らかにされた.デンタルプラーク細菌は, バイオフィルム形成などのために同一菌種だけでなく 他菌種とも会話し, 病原性因子の産生遺伝子を onに したり offにさせる，一筋縄では排除できない賢い連 中といえる.

\section{齿周病原性バイオフィルムは循環障害にかかわる}

動脈硬化のような循環障害には, 高脂血症, 肥満, 契煙, 遺伝的要素などきわめて複雑な因子が関与して 
いる。近年, 第三のクラミジアといわれ呼吸器感染症 にかかわるChlamydia pneumoniaeなどが血流中に入り 込み，血管内皮細胞に侵入して，その部位の動脈硬化 の引き金になっていることが明らかにされだしだー8. そのほか, human cytomegalovirusなども動脈硬化をも たらすものとして注目されてきた。すなわち，動脈硬 化には, 微生物感染が引き金となる炎症性疾患として とらえられるようにもなってきた8.

一方，疫学的な研究を中心にして，歯周病は心臓疾 患に関与しているということが示唆されだした9・12. しかしながら，必ずしも統計学的に相関関係が見いだ されるわけではない，という反論もある ${ }^{13}$.

以前から, 細菌性心内膜症を引き起こすことで知ら れるStreptococcus sanguis（最近，S. sanguinisに变わつ た）の語源は，血液中に見つかるレンサ球菌というこ とに由来する。本菌種は，デンタルプラークに最も多 いレンサ球菌としてバイオフィルムを形成して存在し ている(1). すなわち, デンタルプラークというバイオ フィルムが, 細菌性心内膜炎を引き起こす細菌の供給 源であることがわかる。

私たちは，動脈疾患包埋材料からDNAを抽出し， そこに歯周病原性細菌固有のDNAが存在するか調べ た。抽出した 26 名の患者材料中 6 名の動脈瘤部位に Treponema denticolaの DNA を検出することができた。 さらに，T. denticolaに対する特異抗体で染色したとこ ろ, 動脈瘤の泡沫細胞の周辺に本菌の抗原も検出する ことができた (図 3) ${ }^{15}$.

さらに，心臓外科センターとの共同研究によって， 心冠状動脈疾患部位や動脈狭窄部の動脈壁から DNA を抽出し，歯周ポケット細菌固有のDNAが検出され るか調心゙た。その結果, 歯周病原性Porphyromonas gingivalis, A. actinomycetemcomitans, Campylobacter rectus, Bacteroides forsythus, T. denticola どの DNA が検出されることを明らかにすることができだ ${ }^{16}$ 。こ の事実は，歯周ポケット内細菌が血流中に入り込んで いることを明らかにするものであろう。またこれら の細菌は，血管上皮を含む細胞に侵入することができ ることが証明されている ${ }^{17)}$ 。さらに，動脈硬化促進動

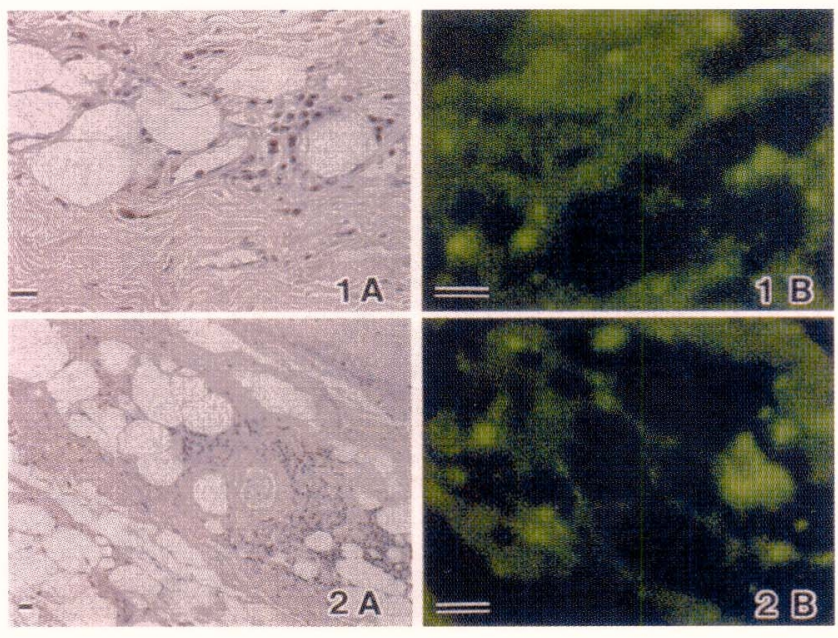

図3 動脈瘤のHE染色 ( 1 A および2A) 泡沫細胞 (foam cell) の周辺に，歯周病原性 Treponema denticolaの抗原（1Bおよ び2B）が検出される，両方の疾患部位から抽出したDNA サンプルには, T. denticola固有のDNA が検出された

物として知られる ApoEノックアウトマウスを高脂肪 食で飼育し，P g ingivalis 菌体を接種すると動脈硬化が さらに促進されることが明らかにされた ${ }^{18}$.

冠状動脈疾患は，死亡要因のトップに位置する。ま た，歯周炎患者はきわめて多い。歯周炎の動脈疾患の かかわりについて，さらに確かな証拠を積み上げてい くことが大切である。古なわち, 歯周病予防の大切さ が的確に認識され，それがへルスプロモーションにな る根拠を積み重ねていかなければならない。

\section{歯周病原性 C. rectusとピロリ菌感染胃疾患との関係}

私たちは, 歯周病原菌と, 胃潰瘍や胃癌のリスク因 子であるピロリ菌 (Helicobacter pylori) 感染との思わ ぬ関連性について明らかにすることができた。私たち は最初，ピロリ菌がヒトの口腔内に常在するか否か調 ベた。その結果, 胃に感染しているヒトの口腔内にも, ピロリ菌固有のDNAをかなりの割合で検出すること ができた。しかしながら，ピロリ菌は培養法によって 検出することができなかった。調べてみると，ヒト口 腔内細菌の多くは，ピロリ菌の発育を抑えるバクテリ オシンを産生することがわかった ${ }^{19}$.20. したがって, ピロリ菌は，ヒトの口腔内では増殖などできないと考 えられる。胃に感染しているものが逆流して, 検出さ 


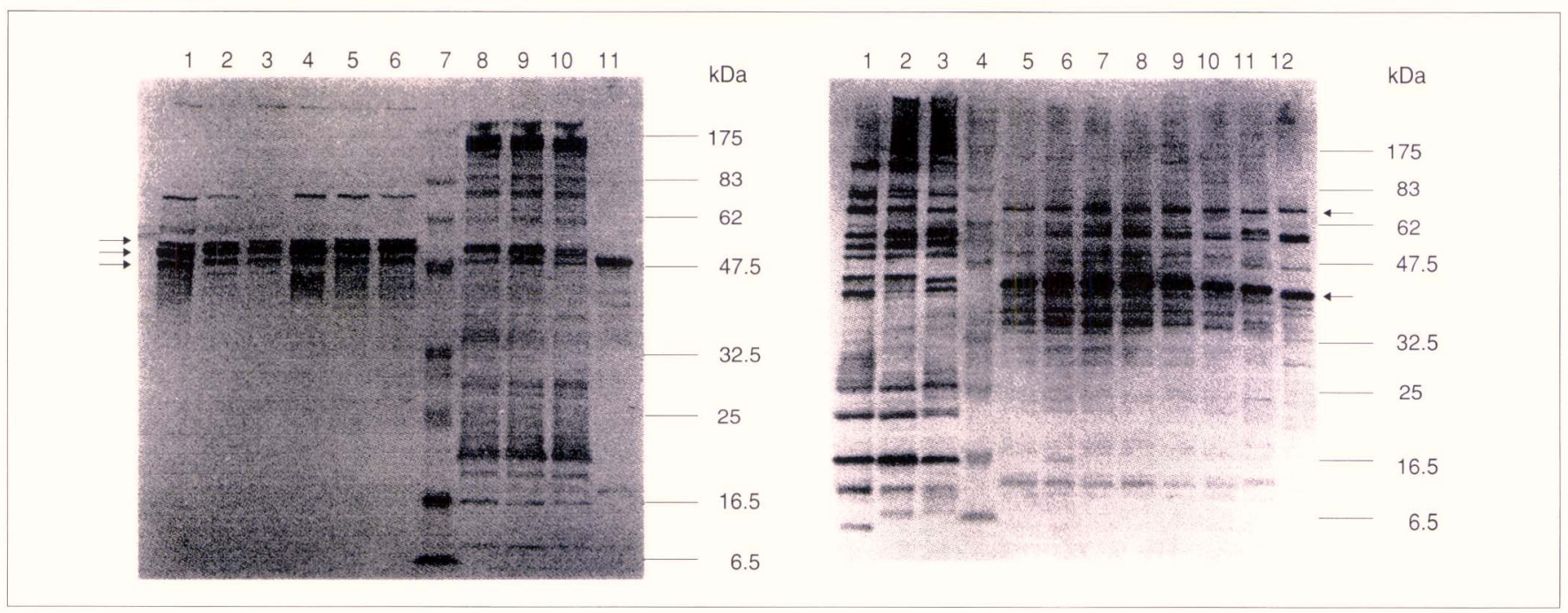

図4 Helicobacter pyloriと Campylobacter rectusは熱ショックタンパク質（HSP）を含む共通する抗原をもっている，左の図は，レーンの1 から 6 までが H. pylori菌株, レーン8から 11 までが C. rectus菌株の抽出抗原, レーンフが分子量マーカーで, H. pyloriに対する抗体で 処理したものである. 右の図は, レーンの 1 から 3 までが H. pylori菌株, レーン 5 から 12 までが C. rectus菌株の抽出抗原, レーン 4 が分子量マーカーで，C. rectusに対する抗体で処理したものである，したがって，両菌種に対する免疫応答は，抗原抗体複合物の生成に 基づくアレルギー性の炎症を引き起こす可能性がある

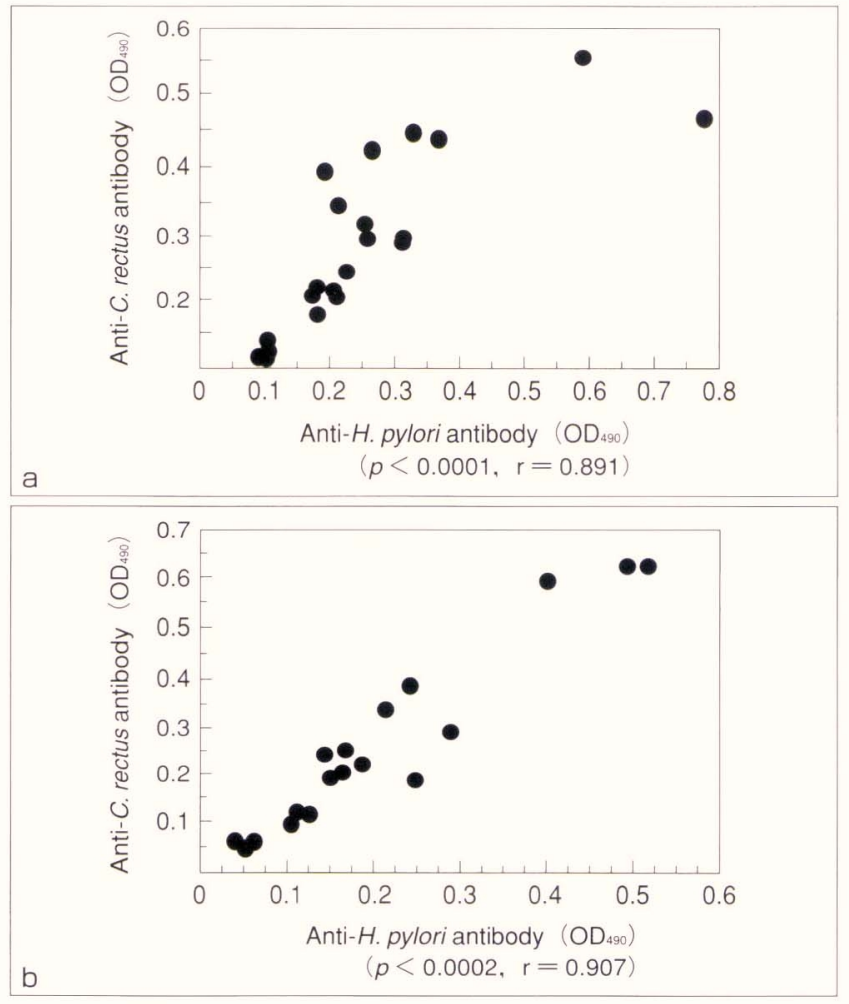

図 5 歯周病患者喠液中の H. pyloriおよびC. rectusに対するIgG (a) 抗体価ならびにlgA (b) 抗体価には相関関係がみられる

\section{れるにすぎないと思われる。}

成人性歯周炎の局所では，運動性のある嫌気性のグ ラム陰性菌群が爆発的に増えている。 その代表的なも
のがC. rectusである。このC. rectus 菌種は, H. pylori と熱ショック蛋白質 (HSP) 在含む共通する抗原をも つことがわかった (図 4) 21!さらに，私たちは歯周 病患者を中心に，血清ならびに唾液中のC. rectusなら びにH. pyloriに対する抗体価を調べた。 その結果, 図 5 に示したように，唾液中の両菌種に対する $\operatorname{IgG} な ら$ びに $\operatorname{Ig} A$ 抗体価には相関があることがわかった。した がって, 両細菌はお互いに免疫応答を引き起こす。こ れらの共通抗原は, 結果として胃粘膜や㐘周組織で抗 原抗体複合物の生成などによるアレルギー性の炎症を もたらす可能性が高いと考えている。

\section{歯周病は一部の掌蹠膿疱症にかかわる}

掌蹠膿疮症は，その原因がよくわかっていない。ま た，完治が簡単にみられない疾患でもある。歯科用金 属による遅延型アレルギーに基づく場合もある。また， 季節的な症状の憎悪もみられるし, 特定のウイルス感 染によるものもあるといわれている。私たちは，その 原因に口腔内慢性感染症が少なからず関与しているこ とを種々検討してきた。

最初に, 茵周病原性グラム院性菌群のHSPが掌蹠膿 疮症に関与しているか否か調べた ${ }^{22}$ 。 その結果, 大腸 


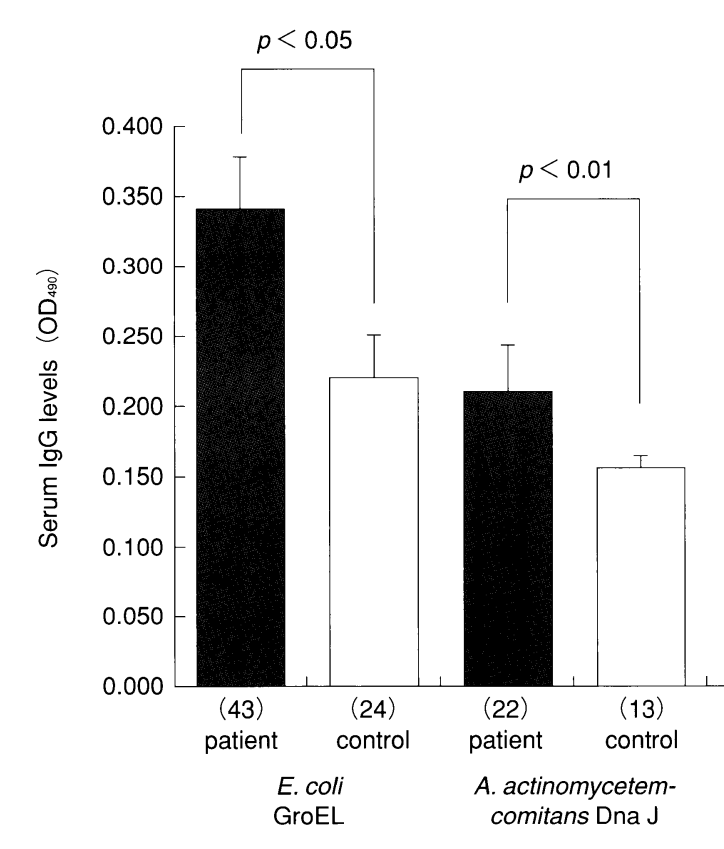

図6 掌蹠膿疮症患者の Esherichia coliの熱ショックタンパク質 GroEL ならびに Actinobacillus actinomycetemcomitansの熱 ショックタンパク質Dna Jに対する血清中のIgG 抗体価は 対照者のそれらの值に比べ，有意に上昇している

菌GroELおよびA. actinomycetemcomitans Dna J両方の HSP に対する歯周病患者血清中の $\operatorname{IgG}$ 抗体価は，歯周 病のない対象グループに比べ有意に上昇していること がわかった (図6 $)^{23}$.また, 私たちは, 多くの歯周病原 性細菌がHSPを産生することを明らかにしてきた。さ らに, 歯周病の治療後, GroELに対する抗体価は有意に 減少することを示すことができた (図 7). HSPに対す る宿主応答の特色は，胸腺ホルモンの作用を受けない $\gamma \delta \mathrm{T}$ 細胞が反応する点である。 $\gamma \delta \mathrm{T}$ 細胞は掌や足の 裏に，より多く存在する。したがって，歯周ポケット 内縁上皮などを通り抜けたHSPが，掌や足の裏で免疫 病理学的応答を引き起こし，それが掌蹠膿疮症の原因 になっていることが考えられる，実際に，歯周病の治 療によって症状の改善がみられた症例は少なくない。

\section{義歯・インプラントのバイオフィルム}

レジン義歯には，C. albicansなどが中心となって， バイオフィルムが形成されることは前述した，真菌で あるC. albicansは，細菌が発育に必要な様々なビ夕ミ

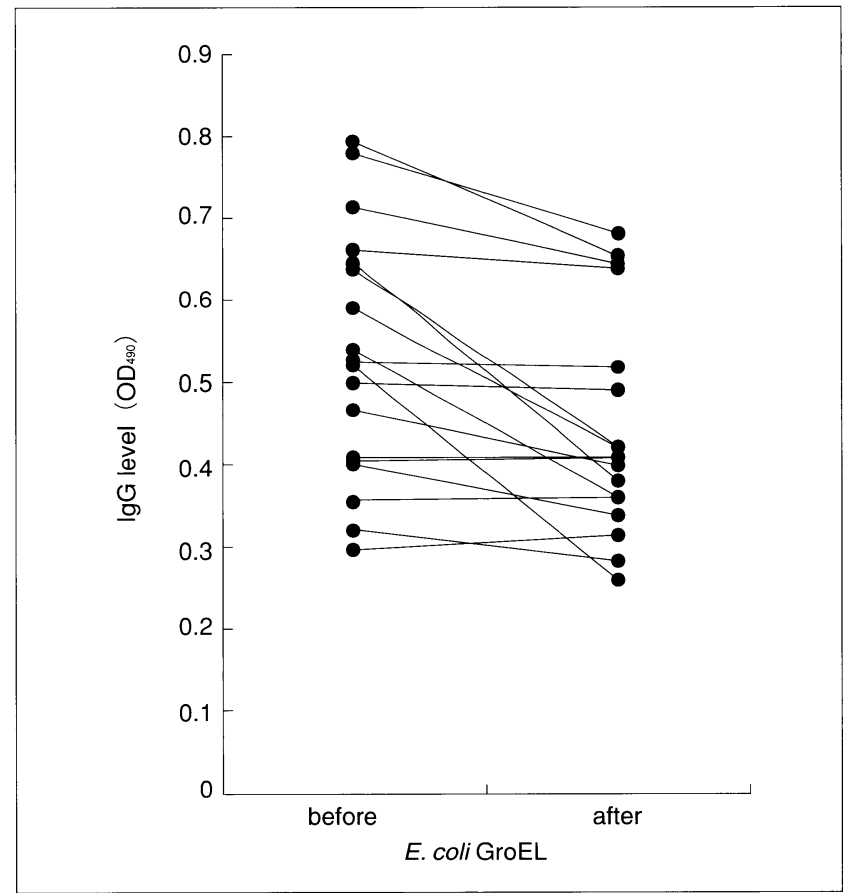

図7 歯周病患者治療前後の熱ショックタンパク質に対するlgG 抗 体価の変化. 歯周病治療によって患者の抗体価が有意に低下 した. この事実は, 歯周局所からの種々の熱ショックタンパ ク質抗原の減少があったことを示すものであろう

ン類を産生する。そのため, メチシリン耐性黄色ブド ウ球菌（Methicillinn-resistant Staphylococcus aureus ; MRSA）を含むブドウ球菌が検出されることも発表し ている ${ }^{23)}$.

私たちは，歯周病原性P. gingivalisが，歯周ポケッ トから osseointegrated implant局所に伝播することを明 らかにした（図 8) ${ }^{24)}$.したがって，インプラント装 着前に，歯周病を治療し，歯周病原性細菌を排除して おくべきであることなどを示唆した.

さらに，歯科インプラントにバイオフィルム形成が 容易に起こらないようなチタン材の前処理には，どの ような方法が適切なのか検討してきている ${ }^{25.26)}$.

\section{定期的な口腔ヶアの意義}

近年, Periodontal medicineなどの言葉が，クローズ アップされてきている。しかし，私たちはそれを新し いものとして認識しているわけではない。歯周病は, 生活習慣に密接にかかわるものの，慢性経過をとるバ イオフィルム感染症である。 それは当然，全身の健康 


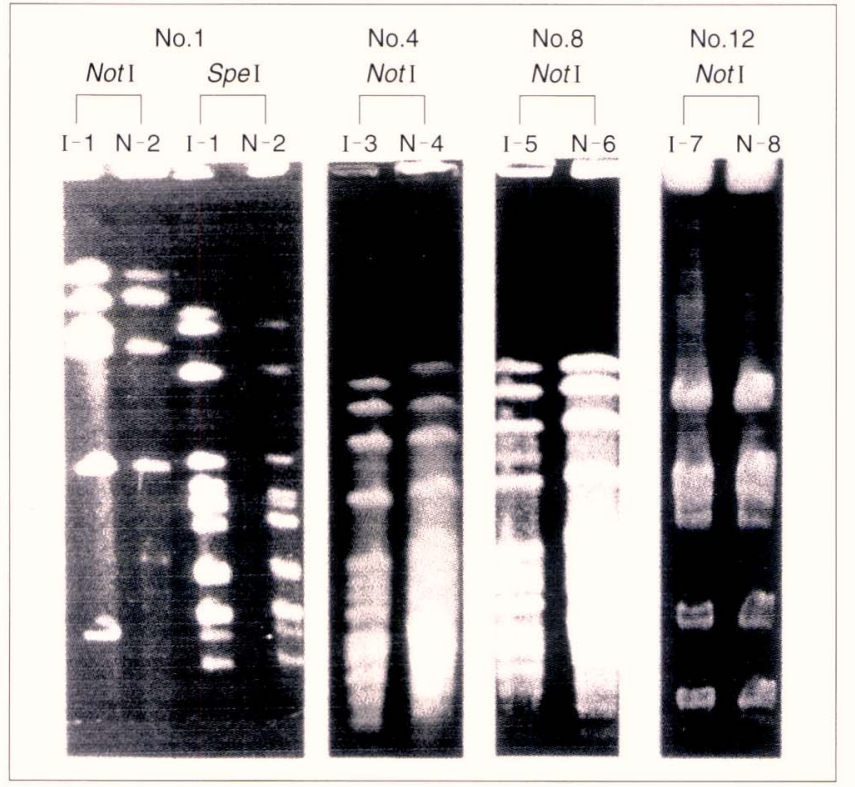

図8 歯周病原性Porphyromonas gingivalisは, osseointegrated implant 周囲に伝播される. No.1, No.4, No.8およびNo.12 は，それぞれの患者である。 Iがインプラント周囲からのP. gingivalis菌株で, Nが天然歯の歯周ポケットからの分離菌株 である。染色体DNAを Not I やSpe I の制限酵素で切断して も, その切断パターンに違いがなく, 天然歯の歯周ポケットか らインプラント周囲に P. gingivalisが伝播したことがいえる

破綻をもたらす細菌の供給源でもある。Glycocalyx で ヌルヌルした状態で頑固にへばりつくバイオフィルム 形成を阻止する新しい薬剂の開発，およびバイオフィ ルムを破壊する免疫学的手段圭確立することは難し い.したがって，メカニカルに取り除くこと以外に， 現段階では適切な除去方法はない.

セルフケアでロ腔清掃ができない要介護者に, 歯科 衛生士が每週メカニカルな方法で口腔内バイオフィル ムを除去してやると, 口腔内のブドウ球菌やC. albicansの菌数を有意に減少させる効果のあることを示し てきた (図 9 $)^{27)}$.さらに, 毎週 1 回の 2 年間にわたる メカニカルなロ腔清掃を中心とした口腔ケアは, 肺炎 による死亡率, 発熱回数ならびに口臭を有意に減少さ せることについても発表してきた（図 10) ${ }^{28}$ 。これら の事実は, 歯周病がバイオフィルム感染症であって, 抗菌剤などの与薬などでの治癒などができない疾患で あることと軌を一にするものであろう。今後, 歯周病 と種々の全身性疾患とのかかわりや, 歯周病の治療に よって様々な疾患の改善がみられるという証拠を，さ

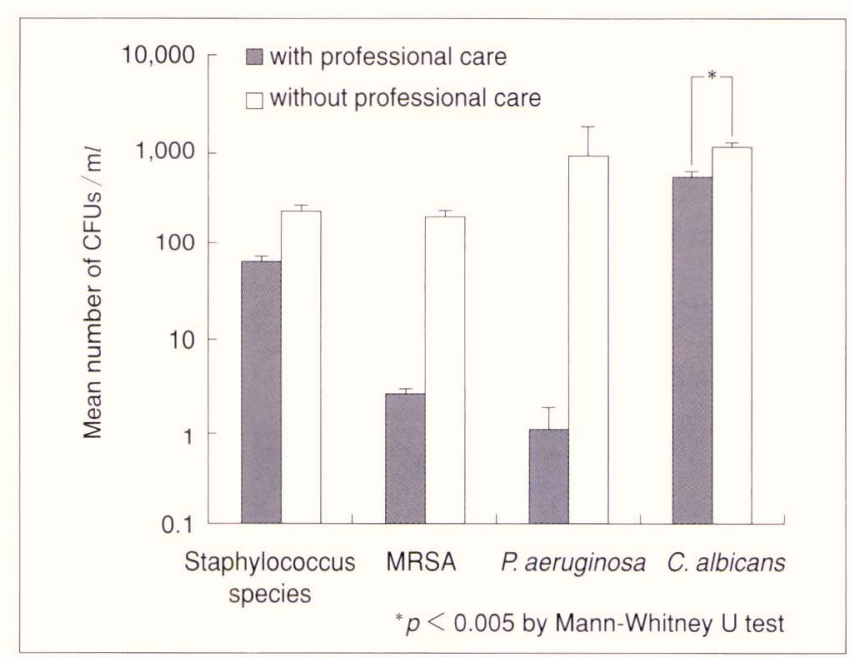

図 9 要介護高齢者に毎週 1 回歯科衛生士による口腔清掃を中心と した口腔ケアを続けると, 口腔内のブドウ球菌, (MRSA), P. aeruginosaならびに C. albicansが減少した

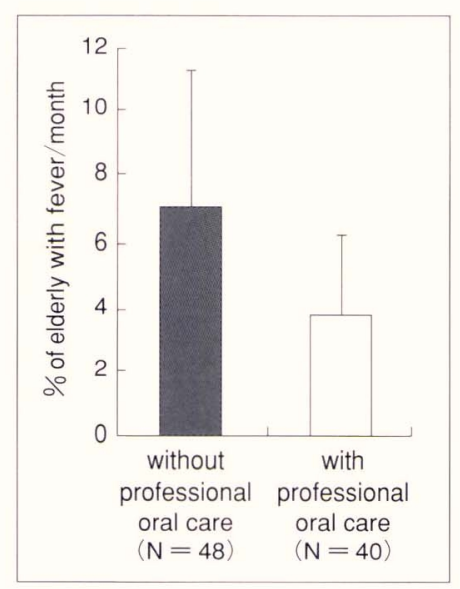

図 10 要介護高齢者に毎週 1 回歯科衛生士によるロ 腔清掃を中心とした口 腔ケアを 2 年間続け ると，その特別養護老 人ホームの高齢者の発 熱回数が減少した

らに積み重ねていくべきである。それらを基礎として， 歯周病の予防や治療がいかに health promotionに大切で あるかを明らかにするものである。

\section{おわりに}

デンタルプラークは, 複数の細菌が会話しながら歯 面に築き上げるバイオフィルムである。宿主防御メカ 二ズムならびに抗菌剂では，立ち问かうことができな い敵である.Glycocalyxでヌルヌルした状態で頑固にへ ばりつくバイオフィルム形成を阻止する新しい薬剂の 開発，およびバイオフィルムを破壊する免疫学的手段 を確立することは難しい.したがって, メカニカルに取 り除くこと以外に, 現段階では適切な除去方法はない. 
デンタルプラーク感染症に対しては, スケーリング やルートプレーニングを基本とした治療を凌駕するも のは見当たらない. 実際には, セルフケアに加えた専 門的ケアを組み込むことが, 口腔内バイオフィルム感 染症への最適な対応といえる。私たちは，口腔内バイ オフィルムとの戦いに勝利できる画期的な手段の開発 に挑戦しなければならない。

\section{参考文献}

1）奥田克爾 : 最新口腔微生物学一バイオフィルム感染症と アレルギー疾患.一世出版 (東京), 2002.

2) 奥田克爾：口腔内バイオフィルム感染症への新たな挑戦. 歯界展望, 99: 1061-1068, 2002.

3) Costerton, J.W., Cheng, K.J., Geesey, G.G., et al. : Bacterial biofilms in nature and disease. Ann. Rev. Microbiol., 41 : 435464, 1987.

4) Costerton, J.W., Stewart, P.S., Greenberg, E.P. : Bacterial biofilms : A common cause of persistent infections. Science, 284 : 1318-1322, 1999.

5) Kolenbrander, P.E. : Oral microbial communities : Biofilms, interactions, and genetic systems. Ann. Rev. Microbiol., 54 : 413-437, 2000.

6) Daus, H., Ozbek, C., Saage, D., et al. : Lack of evidence for a pathogenic role of Chlamydia pneumoniae and cytomegalovirus infection in coronary atheroma formation. Cardiology, $90: 83$ 88, 1998.

7) Parchure,N.,Zouridakis,E.G.,Kaski,J.C. : Effect of azithromycin treatment on endothelial function in patients with coronary artery disease and evidence of Chlamydia pneumoniae infection. Circulation, 19 : 1298-1303, 2002.

8) Ross, R. : Atherosclerosis-an inflammatory disease. N. Engl. J. Med., 340 : 115-126, 1999.

9) Mattila, K.J. : Dental infections as a risk factor for acute myocardial infarction. Eur. Heart J., 14 : 51-53, 1993.

10) Beck, J., Garcia, R., Heis, G., et al. : Periodontal disease and cardiovascular disease. J. Periodontol., 67 : 1123-1137, 1996.

11) Bielanski, W. : Epidemiological study on Helicobacter pylori infection and extragastroduodenal disorders in Polish population. J. Physiol. Pharmacol., 50 : 723-733, 1999.

12) Abou-Raya, S., Naeem, A., Abou-El, K.H., et al. : Coronary artery disease and periodontal disease : is there a link ? Angiology, $51:$ 141-148, 2002.

13) Hujoel, P.P., Drangsholt, M., Spiekerman, C., et al. : Periodontal disease and coronary heart disease risk. JAMA, 284 : 14061410, 2000.

14) Larsen, T., Fiehn, N.E. : Resistance of Streptococcus sanguis biofilms to antimicrobial agents. APMIS, 104 : 280-284, 1996.

15) Okuda, K., Ishihara, K., Nakagawa, T., et al. : Detection of Treponema denticola in atherosclerotic lesions. J. Clin. Microbiol., 39 : 1114-1117, 2001.

16) Ishihara, K., Ito, E., Miyachi, K., et al. : Detection of periodontopathic anaerobes in cardiovasucular disease. (Unpublished data)

17) Rudney, J.D., Chen, R., Sedgewick, G.J. : Intracellular Actinobacillus actinomycetemcomitans and Porphyromonas gingivalis in buccal epithelial cells collected from human subjects. Infect Immun., $69:$ 2700-2707, 2001.

18) Li, L., Messas, E., Batista, E.L. Jr., et al. : Porphyromonas gingivalis infection accelerates the progression of atherosclerosis in a heterozygous apolipoprotein E-deficient murine model. Circulation, $105:$ 861-867, 2002.

19) Ishihara, K., Miura, T., Kimizuka, R., et al. : Oral bacteria inhibit the Helicobacter pylori growth. FEMS Microbial. Lett., $159:$ 355-361, 1997.

20) Okuda, K., Ishihara, K., Miura, T., et al. : Helicobacter pylori may have only transient presence in the oral cavity and the surface of oral cancer. Microbiol. Immun., 44 : 385-388, 2000.

21) Ishihara, K., Miura, T., Ebihara, Y., et al. : Shared antigenicity between Helicobacter pylori and periodontopathic Campylobacter rectus strain. FEMS Microbiol. Lett., 197 : 23-27, 2001.

22) Ishihara, K., Ando, T., Kato, T., et al. : Relationship between the onset of pustulesis parmaris et plantaris, chronic oral infections, and heat shock proteins. Oral Microbiol. Immun., 15 : 232-237, 2000.

23) Ando, T., Kato, T., Ishihara, K., et al. : Heat shock proteins in the human periodontal disease process. Microbiol. Immunol., $39: 321-327,1995$.

24) Honma, K., Tawara, Y., Okuda, K. : Detection of methicillinresistant Staphylococcus aureus in human saliva and on denture surfaces. Bull. Tokyo Dent. Coll., 35 : 217-220, 1994.

25) Sumida, S., Ishihara, K., Kishi, M., et al. : Transmission of periodontal disease-associated bacteria from teeth to osseointegrated implant regions. Int. J. Oral Maxi. Implant, 17 : 696$702,2002$.

26) Yoshinari, M., Oda, Y., Kato, T., et al. : Influence of surface modification to titanium on oral bacterial adhesion in vitro. $\mathrm{J}$. Biomed. Mater. Res., 52 : 388-394, 2000.

27) Yoshinari, M., Oda, Y., Kato, T., et al. : Influence of surface modifications to titanium on antibacterial activity in vitro. Biomaterials, 22 : 2043-2048, 2001.

28) Abe, S., Ishihara, K., Okuda, K. : Prevalence of potential respiratory pathogens in the mouth of professional oral care. Arch. Gerontol. Geriatr., 32 : 45-55, 2001.

28) Adachi, M., Ishihara, K., Abe, S., et al. : The effect of professional oral health care on elderies living in nursing homes. Oral Surg. Oral Med. Oral Pathol. Oral Radiol. Endod., 94 : 191-195, 2002. 